\title{
Heat-related Changes of Density, P-wave Velocity, and Surface Hardness of Granite
}

\author{
Andor Németh" ${ }^{*}$, Ákos Török ${ }^{1}$ \\ ${ }^{1}$ Department of Engineering Geology and Geotechnics, Faculty of Civil Engineering, Budapest University of Technology and Economics, \\ H-1521 Budapest, P.O.B. 91, Hungary \\ * Corresponding author, e-mail: nemeth.andor@edu.bme.hu
}

Received: 04 June 2021, Accepted: 31 August 2021, Published online: 13 September 2021

\begin{abstract}
Low- and intermediate-level radioactive waste is stored in the National Radioactive Waste Repository in Bátaapáti in Hungary. The repository is located in the Carboniferous Mórágy Granite Formation. This paper focuses on heat-related changes of physical properties such as bulk density, P-wave velocity, P-wave modulus, and Duroskop surface hardness of the dominant lithology: monzogranite. Cylindrical specimens were tested at laboratory conditions $\left(22^{\circ} \mathrm{C}\right.$ ) and were heat-treated up to $250{ }^{\circ} \mathrm{C}, 500{ }^{\circ} \mathrm{C}$, and $750^{\circ} \mathrm{C}$. The properties were measured before and after the thermal strain. After heat-treatment, the monzogranite samples became brownish, and at $750^{\circ} \mathrm{C}$, cracks appear at the surface of the specimens. Laboratory test results show that bulk density values slightly decrease from room temperature to $250^{\circ} \mathrm{C}$ treatment and further dropped at $500{ }^{\circ} \mathrm{C}$ and especially at $750{ }^{\circ} \mathrm{C}$. P-wave velocity values and the connected P-wave modulus tend to decrease from room temperature to $750^{\circ} \mathrm{C}$ significantly. Duroskop rebound values show slight declines in the surface strength of the specimens until $500{ }^{\circ} \mathrm{C}$, and then a drastic decline at $750{ }^{\circ} \mathrm{C}$. Heat treatment tends to alter the physical properties of the monzogranite. From room temperature to $500^{\circ} \mathrm{C}$, a slight but apparent decrease between $500{ }^{\circ} \mathrm{C}$ and $750^{\circ} \mathrm{C}$ significant reductions in the bulk density, P-wave velocity, and Duroskop values. Behind the physical alterations are the different thermal-induced expansion of minerals and mineral alteration at elevated temperatures.
\end{abstract}

Keywords

granite, thermal-treatment, bulk density, P-wave velocity, duroskop

\section{Introduction}

Granite is a commonly used material in construction and applied earth science studies [1-3]. It is preferred for general construction use as raw material in civil engineering practice and for building high-volume structures with special requirements. The increasing use of this rock type is the host rock of a subsurface radioactive waste disposal facility, implemented or planned in many countries $[4,5]$.

Low- and intermediate-level radioactive waste has been stored at Bátaapáti National Radioactive Waste Repository Eastern-Mecsek (Hungary). The host rock is the Carboniferous Mórágy Granite Formation.

One of the most important safety considerations for deep geological radioactive waste storage is that excessive temperatures are avoided, and the facility works at normal temperatures. However, during certain failure events (such as heat caused by radioactive waste decay and sudden fire events), the temperature of the facility can reach several hundred degrees of Celsius [6-9]. The consequences of such damage events need to be investigated.
The thermomechanical properties of granitoid rocks have been receiving more attention in the last few decades. Physical and geochemical parameters of the rock are wellknown, thermal-physical property changes are increasingly studied.

Heuze highlighted that strength, density, thermal expansion, latent heat, and melting temperature are well researched; however, topics of physical parameter changes above the $576{ }^{\circ} \mathrm{C}$ transition of quartz, especially above $700{ }^{\circ} \mathrm{C}$, were less well studied [10]. Another study focused on the dynamic mechanical behavior of thermally treated granites such as dynamic strength and dynamic P-wave modulus from room temperature up to $800{ }^{\circ} \mathrm{C}$ [11]. Nondestructive and destructive mechanical testing of heattreated (up to $600{ }^{\circ} \mathrm{C}$ ) specimens of the Mórágy Granite Formation suggested that bulk density and ultrasonic pulse velocity are good indicators of heat-related physical changes of these granites [12]. The latter is significant since the temperature can cause irreversible mechanical 
changes that can influence the stability of underground storage facilities $[13,14]$; hence the stability of radioactive waste disposal sites is primarily controlled by mechanical parameters of the host rock [15].

This paper presents the heat-related changes of physical parameters of monzogranite specimens of the Mórágy Granite Formation. The observed values were mass-, volume-, bulk density, P-wave velocity, and Duroskop rebound changes from room temperature to $250{ }^{\circ} \mathrm{C}, 500{ }^{\circ} \mathrm{C}$, and $750{ }^{\circ} \mathrm{C}$ of heat treatment.

\section{Materials and methods}

The host formation of the repository is a granitoid rock body mainly formed from monzogranite, monzonite, hybrid rocks, veins, and xenoliths [16]. The tested specimens belong to the porphyric monzogranite group of the Mórágy Granite Formation (Fig. 1).

The porphyric monzogranite is a dark reddish grey, phenocrystalline, medium to coarse-grained, inequigranular fresh rock formation with main minerals of quartz $\mathrm{K}$-feldspar and biotite. The pink K-feldspar crystals are megacrysts with a maximum of $3 \mathrm{~cm}$ in diameter. The minerals are hypidiomorphic to rarely xenomorphic. The rock type has an undirected texture in the examined zone of the core drill. [16]

Altogether, 24 pieces of cylindrical samples with an average diameter of $4.73 \mathrm{~cm}$ and a 2:1 (height/width) ratio were prepared for treatment and laboratory tests. All in all 4 groups $\left(22^{\circ} \mathrm{C}, 250{ }^{\circ} \mathrm{C}, 500{ }^{\circ} \mathrm{C}, 750{ }^{\circ} \mathrm{C}\right)$ were examined, in each group, 6 specimens were tested to determine statistical values.

The samples were cut to shape from NQ-sized cores with a water-cooling diamond cutting disc (Fig. 2(a)). The samples were dried out to an air-dry state then mass, volume (i.e., bulk density), ultrasound velocity measurements, and surface hardness measurements were carried out (Fig. 3(a) and (b)). Bulk density values were measured according to EN 1936:2007 European Normative [17]. Ultrasound P-wave velocity values of the specimens were recorded with a PUNDIT device according to EN 14579:2005-01

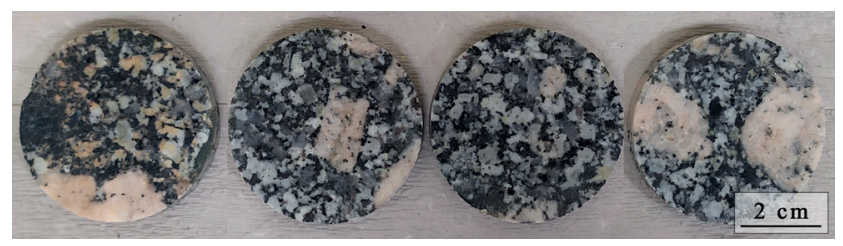

Fig. 1 Macroscopic texture of porphyritic monzogranite samples of the Mórágy Granite Formation standard [18]. The surface strength was measured with a non-standardized Duroskop test with a frame for testing cylindrical samples [19].

The heat-treatment of the samples was carried out in a Carbolite ABA 7/35 electric oven (Fig. 2(b)). During the treatment, heating was performed at $20^{\circ} \mathrm{C} / \mathrm{min}$ until the desired 250 or 500 or $750{ }^{\circ} \mathrm{C}$ was reached. The heat treatment was then carried out for 4 hours to allow the appropriate thermal homogenization to occur; after then, the samples were cooled to room temperature at an average rate of $5{ }^{\circ} \mathrm{C} / \mathrm{min}$. The samples were then re-tested for bulk density, ultrasound propagation velocity, and Duroskop surface strength, so the initial, pre-heat-treatment, and post-heat-treatment results could be compared, not just between the post-heat-treated groups (Fig. 3(a) and (b)).

\section{Results}

After heat treatment, the monzogranite samples underwent visible and measurable physical changes. In addition to the parameterized factors, the colors and texture of the specimens were also transformed (Fig. 4). A graydark gray base color characterizes the monzogranite at $22{ }^{\circ} \mathrm{C}$. In contrast, after heat treatment at $250{ }^{\circ} \mathrm{C}$, small yellowish-brown spots appeared on the surface of the specimens. After the thermal treatment from $22{ }^{\circ} \mathrm{C}$ to $500{ }^{\circ} \mathrm{C}$, the whole sample had a pale yellowish-brown base color. The most significant transformation occurred at $750{ }^{\circ} \mathrm{C}$ of thermal treatment. The specimens showed a yellowish-reddish-brown color transition, and visible

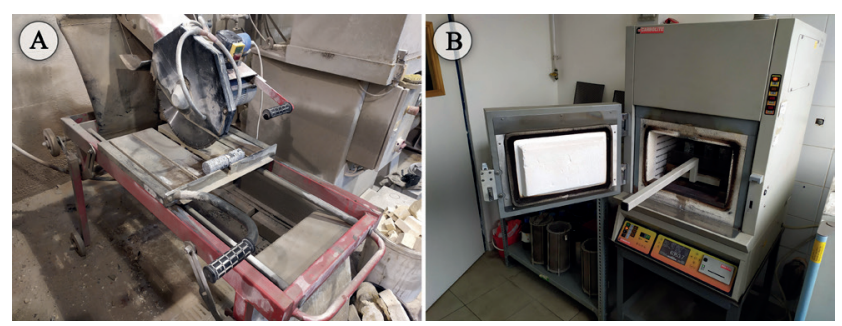

Fig. 2 Instruments for preparation of the monzogranite specimens. a) Cutting of the drill cores, b) Thermal treating in an electric oven
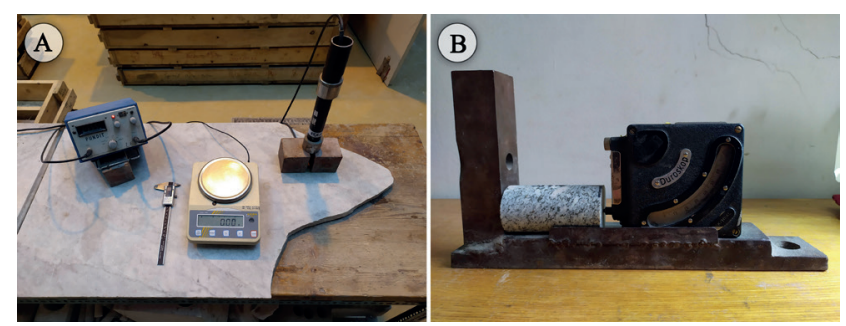

Fig. 3 Instruments for testing the monzogranite specimens a) Bulk density and P-wave velocity measurements, b) Duroskop test 

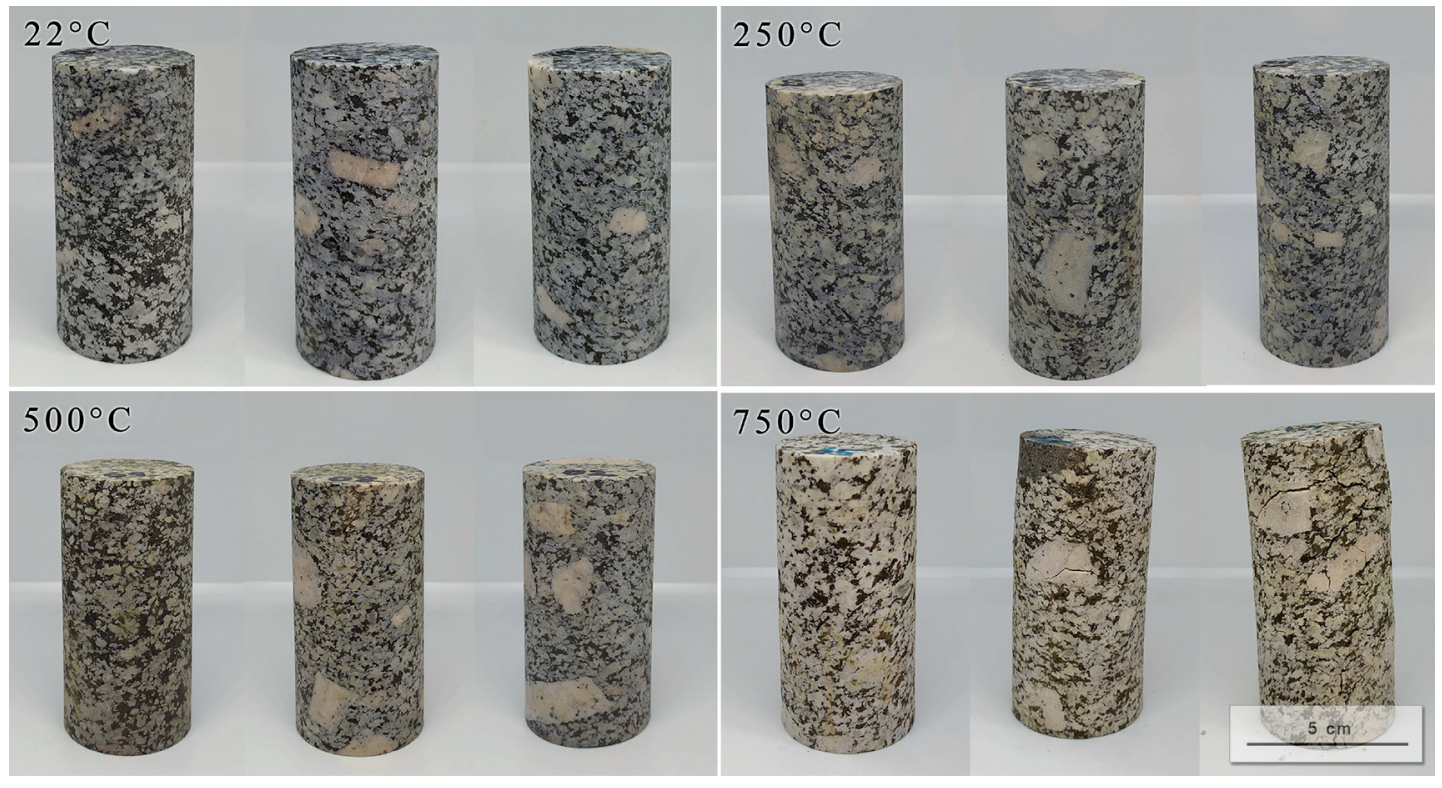

Fig. 4 Thermal-treated cylindrical samples of the porphyritic monzogranite rock formation. Color change is more significant at higher temperatures

macro-cracks appeared on the surface of the samples. Among the primary phases of the rock, the whitening of the gray and light pale pink feldspars appeared, thus separating the light quartz and feldspar from the biotitic phases transformed them into dark red (Fig. 4).

In terms of measured physical parameters, the mean bulk density value at room temperature $\left(22{ }^{\circ} \mathrm{C}\right)$ is $2714.2 \mathrm{~kg} / \mathrm{m}^{3}$. After $250{ }^{\circ} \mathrm{C}$ heat-treatment, $1.28 \%$ decrease-, at $500{ }^{\circ} \mathrm{C}$ $0.82 \%$ decrease- and at $750{ }^{\circ} \mathrm{C}$ heat-treatment, $8.03 \%$ decrease in bulk density mean values occurred (Table 1).

The heat-treated bulk density values show that at $500{ }^{\circ} \mathrm{C}$, the bulk density decrease is slighter than the decrease at $250^{\circ} \mathrm{C}$; however, at $750{ }^{\circ} \mathrm{C}$, a significant reduction of bulk density values occurs (Fig. 5).

Table 1 The sample mean and standard deviation results of physical parameters before heat-treatment $\left(22^{\circ} \mathrm{C}\right)$ and after $\left(250^{\circ} \mathrm{C}, 500^{\circ} \mathrm{C}\right.$, and $750{ }^{\circ} \mathrm{C}$ ) heat-treatment

\begin{tabular}{lcccccc}
\hline $\begin{array}{l}\text { Thermal } \\
\text { treatment }\end{array}$ & \multicolumn{2}{c}{$\begin{array}{c}\text { Bulk density } \\
(\mathrm{Std})\end{array}$} & $\begin{array}{c}\text { P-wave velocity } \\
(\mathrm{Std})\end{array}$ & \multicolumn{2}{c}{$\begin{array}{c}\text { Duroskop value } \\
(\mathrm{Std})\end{array}$} \\
& \multicolumn{2}{c}{$\left[\mathrm{kg} / \mathrm{m}^{3}\right]$} & \multicolumn{2}{c}{$[\mathrm{km} / \mathrm{s}]$} & \multicolumn{2}{c}{$[-]$} \\
& before & after & before & after & before & after \\
\hline $22{ }^{\circ} \mathrm{C}$ & 2716.0 & & 5.29 & & 51 & - \\
& $(23.6)$ & & $(0.25)$ & - & $(0.4)$ & \\
& 2712.9 & 2678.1 & 5.29 & 4.49 & 51 & 49 \\
$250{ }^{\circ} \mathrm{C}$ & $(7.5)$ & $(34.0)$ & $(0.15)$ & $(0.16)$ & $(0.5)$ & $(0.4)$ \\
& 2716.9 & 2694.7 & 5.09 & 3.32 & 50 & 47 \\
$500{ }^{\circ} \mathrm{C}$ & $(22.9)$ & $(27.1)$ & $(0.36)$ & $(0.20)$ & $(0.8)$ & $(0.7)$ \\
& 2710.9 & 2493.3 & 5.26 & 0.76 & 51 & 19 \\
$750{ }^{\circ} \mathrm{C}$ & $(5.7)$ & $(106.1)$ & $(0.16)$ & $(0.25)$ & $(0.8)$ & $(5.9)$ \\
\hline
\end{tabular}

P-wave velocity shows a uniform decrease after different thermal-treatment processes. The average of $5.22(0.24)$ $\mathrm{km} / \mathrm{s}$ P-wave velocity at room temperature significantly decreases after heat treatment. After $250{ }^{\circ} \mathrm{C}, 2.49 \%$ decrease in velocity-, after $500{ }^{\circ} \mathrm{C}$ of treatment, $34.41 \%$ and after $750{ }^{\circ} \mathrm{C}$ of heat-treatment, $85.69 \%$ of P-wave velocity decrease occurred compared to room temperature values (Fig. 6).

The average Duroskop rebound values of the untreated samples are 51 , with a 0.8 standard deviation. As the results show, the surface strength slightly decreases to 49 at $250^{\circ} \mathrm{C}$, 47 at $500^{\circ} \mathrm{C}$, and then significantly drops to 19 at $750^{\circ} \mathrm{C}$.

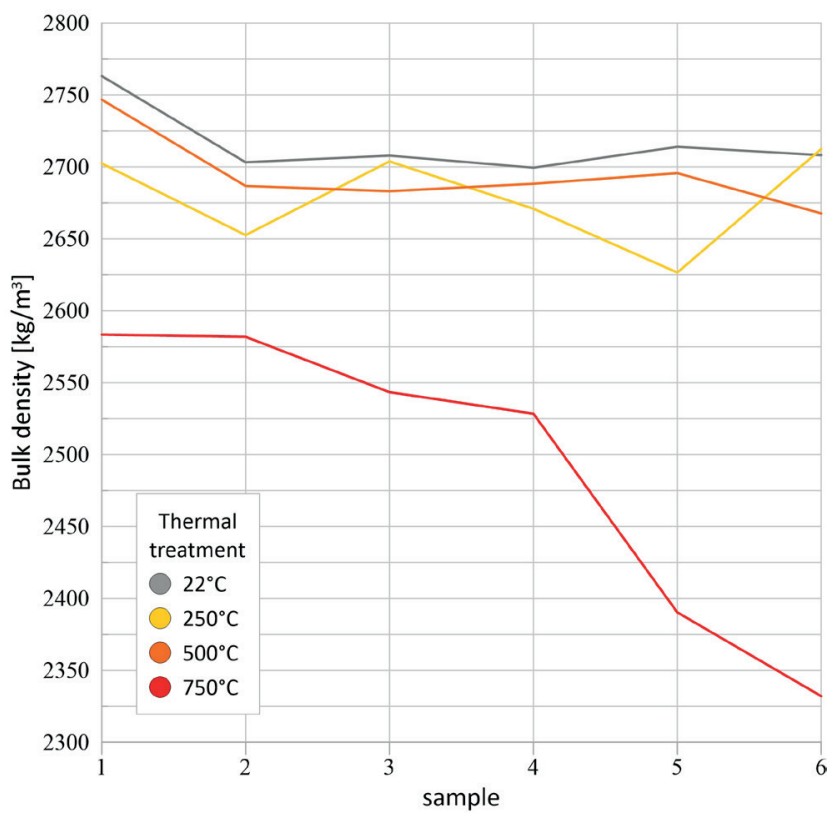

Fig. 5 Line plot of Bulk density values 


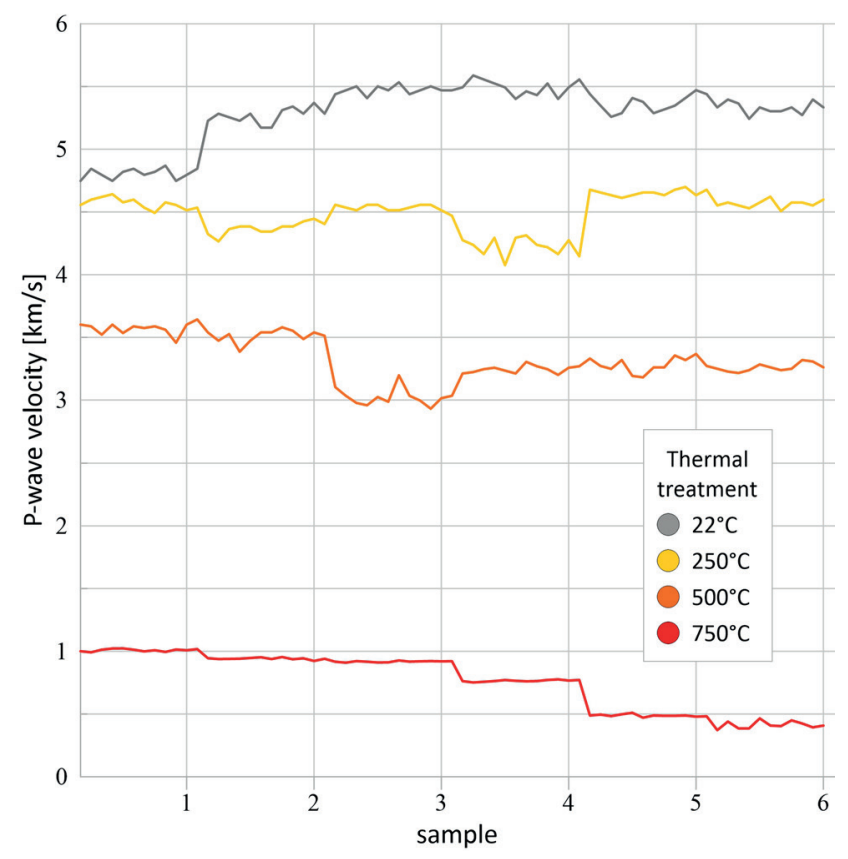

Fig. 6 Line plot of P-wave velocity values

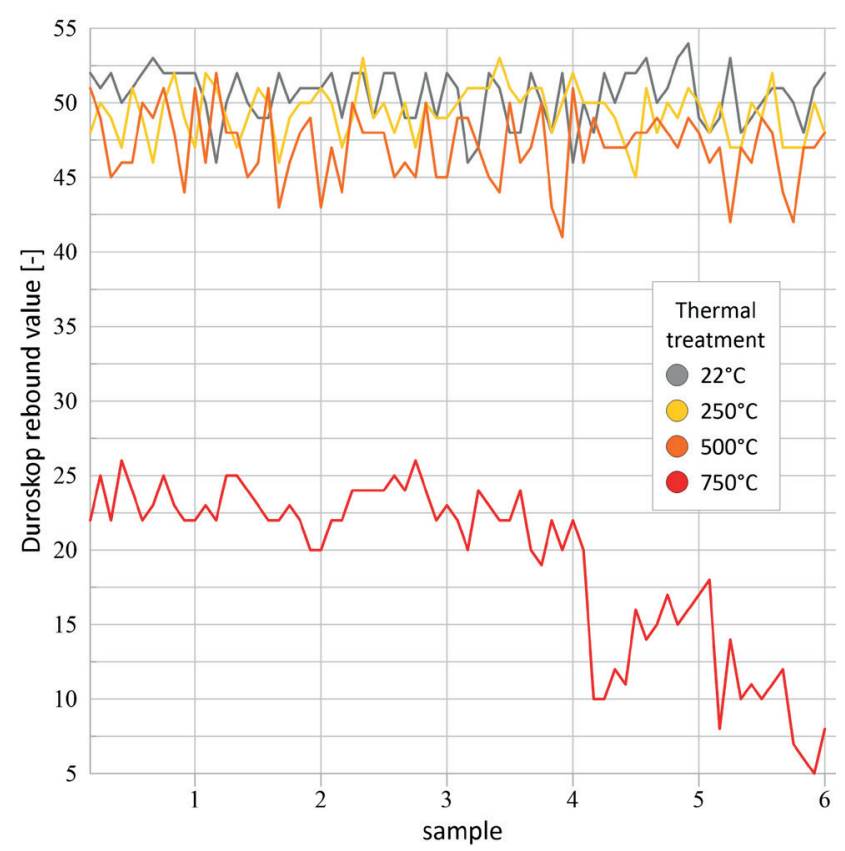

Fig. 7 Line plot of Duroskop values

Duroskop values tend to scatter more than bulk density and P-wave velocity values (Table 1). The measurement method is made on a point-by-point basis, and the rebound value of individual minerals behaves differently at room temperature and after heat treatment (Fig. 7).

It is possible to determine the P-wave modulus of elasticity values (M) for each sample from bulk density and P-wave velocity results [11, 20] (Fig. 8). Results show a linear decrease from standard room temperature to elevated temperatures. P-wave modulus shows a linear correlation with temperature with a high R-value of $98 \%$.

\section{Discussion}

Non-destructive material testing methods are suitable for detecting physical alterations of the monzogranite samples at elevated temperatures.

Heat-treatment of the monzogranite samples visibly changed the color of the specimens at elevated temperatures. At high temperatures (as $750^{\circ} \mathrm{C}$ ), not just micro-, but macrocracks developed due to mineral alterations and the uneven thermal expansion of the individual minerals [11, 21, 22]. These processes changed the mass, volume, bulk density, ultrasonic pulse velocity, and rock surface hardness (Fig. 9).

Heat-treatment processes carried out slight mass decreases and significant volume increase at higher temperatures. Therefore, the parameter is driven mainly by the volume change of the tempering.

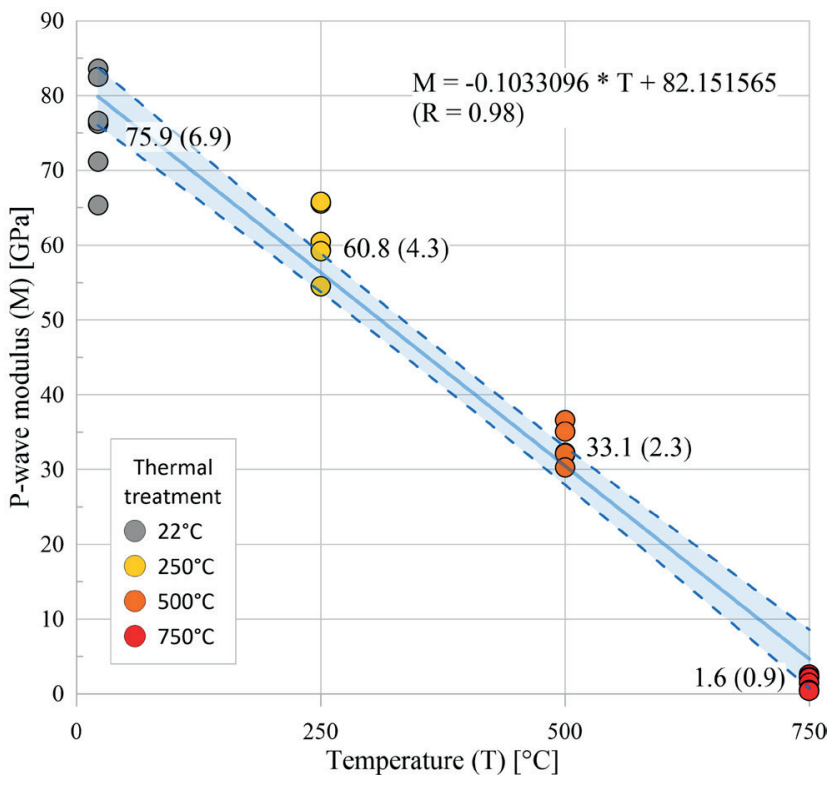

Fig. 8 P-wave modulus (M) of the standard and heat-treated granite samples with the mean values and standard deviations. The results show linear correlation with an $\mathrm{R}$ of $98 \%$

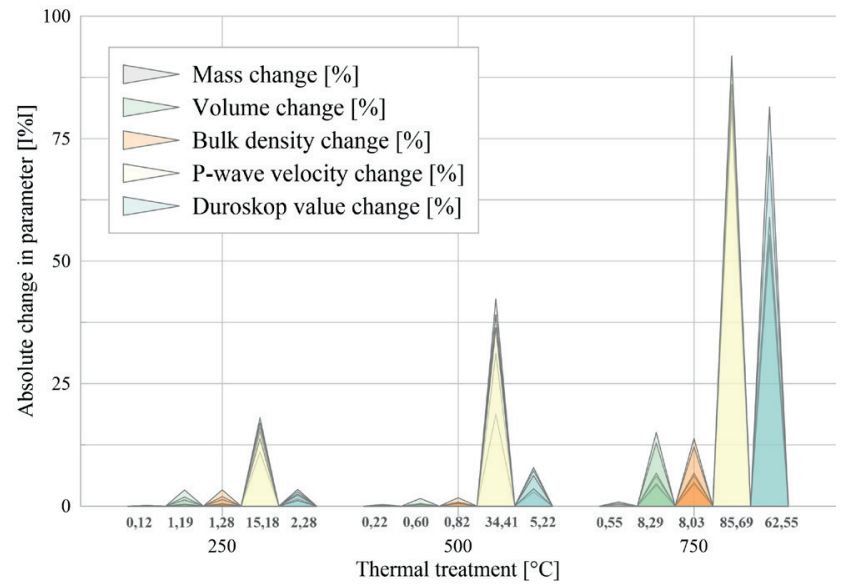

Fig. 9 Absolute data Bar Plot of sample groups, after heat treatment 
Bulk density values decrease at $250{ }^{\circ} \mathrm{C}$ followed by a minor increase at $500{ }^{\circ} \mathrm{C}$ and a significant decrease at $750{ }^{\circ} \mathrm{C}$. Heated samples have lower densities than nonheated ones.

The P-wave velocities clearly show that heat-treatment rapidly and uniformly decreasing ultrasonic pulse values. Former papers suggest $[11,21]$ that micro-cracks are formed during the heating of granitic rocks. Therefore, slower velocities occur at higher temperatures. P-wave velocity seems to be the best way to indicate the thermal behavior of the monzogranite as all measured results show distinguished and continuously decreasing data between heat-treated groups.

Duroskop results show that surface strength decreases significantly at higher temperatures; however, from 250$500{ }^{\circ} \mathrm{C}$ thermal treatment, slight change occurs between groups. The scatter of the Duroskop data suggests that the method is less sensitive than the P-wave velocity values as different crystals tend to have different rebound values.

In terms of P-wave modulus, it can be stated that the specimens gradually lose their elasticity with increasing temperature. The M-modulus is a function of the $2^{\text {nd }}$ power of the P-wave velocity; therefore, it is easy to see that this loss of elasticity is strongly related to the decrease in P-wave propagation velocities, and thus to the formation of micro- and macro-fractures at high temperatures $[11,21,22]$. As for the P-wave velocity results, it can be stated that the M-modulus is one of the best ways indicating thermal-treatment-related physical degradations in the monzogranite.

In the term of combined bulk density, P-wave velocity and Duroskop values show, that the most significant change in both three values tends to decrease significantly between $500{ }^{\circ} \mathrm{C}$ and $750{ }^{\circ} \mathrm{C}$. As the ternary class scatters (Fig. 10) indicate, relative percentages of the examined physical parameters form a distinct population at $750{ }^{\circ} \mathrm{C}$ from $250{ }^{\circ} \mathrm{C}$ and $500{ }^{\circ} \mathrm{C}$. Between $500^{\circ} \mathrm{C}$ and $750{ }^{\circ} \mathrm{C}$ mineral alterations and related expansions (such as $\alpha$-quartz to $\beta$-quartz inversion at $573{ }^{\circ} \mathrm{C}$ ) and the thermal expansion difference of main rock-forming minerals cause micro-, and macro cracking inside and on the outer surface of the specimens [11, 21, 22]. This cracking development significantly and permanently increases volume, decreases bulk density-, P-wave velocity- and Duroskop surface strength values. The decrease in ultrasonic pulse velocity at elevated temperatures has been observed at granites [22] and concrete [23].

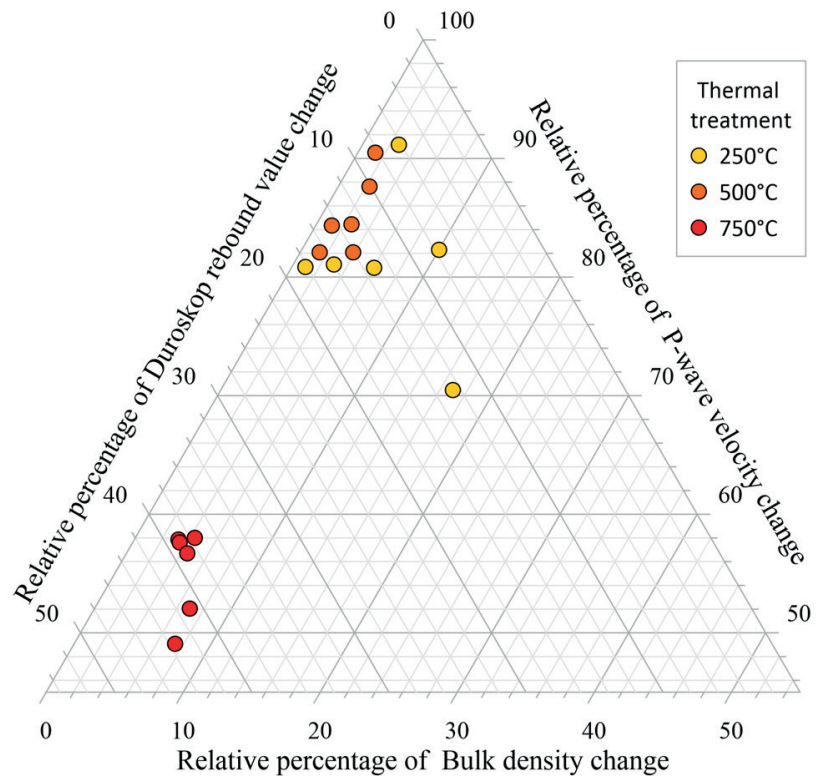

Fig. 10 Ternary class scatter plot of bulk density-, P-wave velocity-, and Duroskop value changes

For further research, the resolution of heat-treatment between $500{ }^{\circ} \mathrm{C}$ and $750{ }^{\circ} \mathrm{C}$ is inevitable to reveal the exact limit of physical decrease to the host rock.

\section{Conclusions}

Monzogranite, the host rock of the National Radioactive Waste Storage Facility of Hungary, suffered alteration due to thermal experiments at $250^{\circ} \mathrm{C}, 500{ }^{\circ} \mathrm{C}$, and $750{ }^{\circ} \mathrm{C}$.

Heat-treatment caused brownish, then reddish color changes in the samples, which is more prominent at higher temperatures. At $750{ }^{\circ} \mathrm{C}$, macro-cracks appeared on the surface of the specimens. Mineral changes and thermal expansion differences of main rock-forming minerals caused a change in the physical properties of the monzogranite samples.

Bulk density values tend to decrease at $250{ }^{\circ} \mathrm{C}$ then increase at $500{ }^{\circ} \mathrm{C}$. At $750{ }^{\circ} \mathrm{C}$ drastic decrease occurs in values, which is connected to the volume change in the samples.

P-wave velocity and the highly connected P-wave modulus $(\mathrm{M})$ reduction due to high temperature is uniform and significant and seems to be the best way to indicate the thermal behavior of the monzogranite of the examined physical properties. P-wave velocity change Is connected to the micro-cracking development of the specimens.

Duroskop values decrease slightly until $500{ }^{\circ} \mathrm{C}$, then significantly at $750{ }^{\circ} \mathrm{C}$. Surface strength changes can be assessed with Duroskop at elevated temperatures, but it 
seems very sensitive to smaller-scale surface strength changes, and larger individual crystals can influence the rebound values.

\section{Acknowledgment}

We would like to thank the employees of RHK Ltd. for offering the samples, and related documents, especially the

\section{References}

[1] Sajid, M., Coggan, J., Arif, M., Andersen, J., Rollinson, G. "Petrographic features as an effective indicator for the variation in the strength of granites", Engineering Geology, 202, pp. 44-54, 2016. https://doi.org/10.1016/j.enggeo.2016.01.001

[2] Gunes Yilmaz, N., Goktan, R. M., Kibici, Y. "An investigation of the petrographic and physico-mechanical properties of true granites influencing diamond tool wear performance, and development of a new wear index", Wear, 271, pp. 960-969, 2011.

https://doi.org/10.1016/j.wear.2011.04.007

[3] Sousa, L. M. O. "Petrophysical properties and durability of granites employed as building stone: a comprehensive evaluation", Bulletin of Engineering Geology and the Environment, 73(2), pp. 569-588, 2014.

https://doi.org/10.1007/s10064-013-0553-9

[4] Gálos, M., Gyurika, I. G. "Quality measuring numbers of milled edges of granite surfaces", Periodica Polytechnica Civil Engineering, 58(2), pp. 121-129, 2014. https://doi.org/10.3311/PPci.2158

[5] Li, Y., Zhai, Y., Wang, C., Meng, F., Lu, M. "Mechanical properties of Beishan granite under complex dynamic loads after thermal treatment", Engineering Geology, 267, Article number: 105481, 2020. https://doi.org/10.1016/j.enggeo.2020.105481

[6] Finsterle, S., Muller, R. A., Baltzer, R., Payer, J., Rector, J. W. "Thermal Evolution near Heat-Generating Nuclear Waste Canisters Disposed in Horizontal Drillholes", Energies, 12(4), Article number: 596, 2019.

https://doi.org/10.3390/en12040596

[7] Sirdesai, N. N., Singh, T. N., Pathegama Gamage, R. "Thermal alterations in the poro-mechanical characteristic of an Indian sandstone - A comparative study", Engineering Geology, 226, pp. 208-220, 2017.

https://doi.org/10.1016/j.enggeo.2017.06.010

[8] Hajpál, M., Török, Á. "Physical and mineralogical changes in sandstones due to fire and heat", Environmental Geology, 46, pp. 306312, 2004.

https://doi.org/10.1007/s00254-004-1034-z

[9] Kourkoulis, S. K. (ed.) "Fracture and Failure of Natural Building Stones: Applications in the Restoration of Ancient Monuments", Springer, Dordrecht, Netherlands, 2007. https://doi.org/10.1007/978-1-4020-5077-0

[10] Heuze, F. E. "High-temperature mechanical, physical and thermal properties of granitic rocks - a review", International Journal of Rock Mechanics and Mining Sciences \& Geomechanics Abstracts, 20(1), pp. 3-10, 1983.

https://doi.org/10.1016/0148-9062(83)91609-1 help of Patrik Török is appreciated. Anikó Laufer helped in the laboratory works. Furthermore, we would like to thank the Department of Highway and Railway Engineering for using their electric oven. The financial support of TKP2020 Institution Excellence Subprogram, Grant No. TKP2020 BME-IKA-VÍZ of the National Research Development and Innovation Office of Hungary is acknowledged.

[11] Fan, L. F., Wu, Z. J., Wan, Z., Gao, J. W. "Experimental investigation of thermal effects on dynamic behavior of granite", Applied Thermal Engineering 125, pp. 94-103, 2017. https://doi.org/10.1016/j.applthermaleng.2017.07.007

[12] Török, A., Török, Á. "The effect of temperature on the strength of two different granites", Central European Geology, 58(4), pp. 356369, 2015. https://doi.org/10.1556/24.58.2015.4.5

[13] Kovács, L., Mészáros, E., Vásárhelyi, B. "Comparison of data of in situ geotechnical measurements taken during the construction of differently designed disposal chambers", In: ISRM Regional Symposium - EUROCK 2015, Salzburg, Austria, 2015, pp. 651-656.

[14] Somodi, G., Krupa, Á., Kovács, L. Vásárhelyi, B. "Comparison of different calculation methods of Geological Strength Index (GSI) in a specific underground construction site", Engineering Geology, 243, pp. 50-58, 2018. https://doi.org/10.1016/j.enggeo.2018.06.010

[15] Rozgonyi-Boissinot, N., Buocz, I., Hatvani, I. G. Török, Á. "Shear strength testing of consolidated claystones: breakpoint detection of shear stress versus shear displacement curves, a statistical approach", International Journal of Geomathematics, 12, Article number: 1, 2021. https://doi.org/10.1007/s13137-020-00168-6

[16] Király, E. "A Mórágyi Gránit Formáció petrográfiája és ásványkémiai jellemzése" (Petrography and mineralogical characterisation of the Mórágyi Granite Formation), In: Balla, Z., Gyalog, L. (eds.) A Mórágyi-rög északkeleti részének földtana (Geology of the north-eastern part of the Mórágy Block), Geological Institute of Hungary, Budapest, Hungary, 2009, pp. 207-223. (in Hungarian) [online] Available at: https://mbfsz.gov.hu/sites/default/files/file/ 2018/03/23/bataapati_magyarazo.pdf

[17] CEN "EN 1936:2006 Natural stone test methods. Determination of real density and apparent density, and of total and open porosity", European Committee for Standardization, Brussels, Belgium, 2006.

[18] CEN "EN 14579:2005 Natural stone test methods - Determination of sound speed propagation", European Committee for Standardization, Brussels, Belgium, 2005.

[19] Török, Á. "Non-destructive Surface Strength Test - Duroskop a Forgotten Tool; Comparison to Schmidt Hammer Rebound Values of Rocks", In: IAEG XIII Congress and AEG 61st Annual Meeting, San Francisco, California, 2019, pp. 129-135. https://doi.org/10.1007/978-3-319-93142-5_18

[20] Mavko, G., Mukerji, T., Dvorkin, J. "The Rock Physics Handbook", Cambridge University Press, Cambridge, UK, 2003. https://doi.org/10.1017/CBO9780511626753 
[21] Yang, S.-Q., Ranjith, P. G., Jing, H.-W., Tian, W.-L., Ju, Y. "An experimental investigation on thermal damage and failure mechanical behavior of granite after exposure to different high-temperature treatments", Geothermics, 65, pp. 180-197, 2017.

https://doi.org/10.1016/j.geothermics.2016.09.008

[22] Zhu, Z., Ranjith, P. G., Tian, H., Jiang, G., Dou, B., Mei, G. "Relationships between P-wave velocity and mechanical properties of granite after exposure to different cyclic heating and water cooling treatments", Renewable Energy, 168, pp. 375-392, 2021.

https://doi.org/10.1016/j.renene.2020.12.048
[23] Torić, N., Boko, I., Juradin, S., Baloević, G. "Mechanical properties of lightweight concrete after fire exposure", Structural Concrete, 17(6), pp. 1071-1081, 2016.

https://doi.org/10.1002/suco.201500145 